\title{
AN OVERVIEW OF TELEPHONY DEVELOPMENT IN ZAGREB (1881-1981)
}

\author{
Goran RAJIČ*
}

Within a mere hundred years from the appearance of the first telephone in Zagreb in 1881 until the establishment of the first electronic telephone exchange in 1981, telephony in Zagreb went through several formative periods to assert itself. Zagreb was transformed from a provincial town in the Austrian-Hungarian Monarchy to the economic and cultural centre of Croatia. In that period, due to technological development, many changes took place that influenced the accessibility and price of the most popular telecommunications technology in the $20^{\text {th }}$ century. At first a status symbol reserved for the wealthiest citizens, telephone gradually became accessible to all inhabitants of the city. In the decades after World War II, the new telephone infrastructure was constructed under the unfavourable conditions of technological underdevelopment, scarcity of professionals, and meagre financial resources. Nevertheless, despite all the aggravating circumstances, telephony managed to become an inevitable part of Zagreb's everyday life. Modern telecommunications rest on these very steps that fixed telephony took in its development, and are therefore an indicator of the technological as well as cultural development of Zagreb.

Keywords: telephony, telecommunications development, Zagreb, telecommunications

1 This research has been financed by the Croatian Science Foundation, project IP-2016-06-2015: Modernization of Urban Life in Croatia through the Prism of Communal Infrastructure Development in the $19^{\text {th }}$ and $20^{\text {th }}$ Centuries.

Goran Rajič, Hrvatski Telekom Museum, Zagreb, Croatia 


\section{Introduction}

The economic development and political organization of any society closely correlate with the degree of telephony development. The possibilities and freedom of communication are at the heart of every democratic society, and regular functioning of its economy requires a smooth flow of information. In the 20th century, these requirements were largely met through telephony. Bearing this in mind, we can say that in Zagreb during the period in question (1881-1981) telephony did not develop fully in accordance with the needs of the city's inhabitants and its commercial organizations. From the very beginning of its development, it was subject to politics and economic protectionism, suffered from technological backwardness, and thus remained largely inaccessible to the wider public until the late 20th century. In this paper, based on the available sources (primarily the Archive and the Collection of the Croatian Telephony (HT) Museum, which is the national postal and telecommunications museum of the Republic of Croatia, the periodicals of PTT Zagreb, and other available publications), I will reconstruct the timeline of telephony development in the city of Zagreb, including the evolution of a public telephone network, its automation by introducing the "step-by-step" switchboard, its decentralization by using the "crossbar" technology, and eventually its entry into the era of electronic telephone connections. So far, two important studies have been published on the topic of telecommunications development in Zagreb, but the subject has not been researched adequately considering its social significance. The book Hundred Years of Telephony in Croatia by Velimir Sokol, published in 1981, deals mainly with events related to the emergence of the first public telephone network in Zagreb, while Nedjeljko Nižić's Overview of the History of Postal, Telegraph, and Telephone Services in Croatia from 2007 offers a succinct review of telephony until the interwar period in Croatia.

The history of modern telecommunications in Croatia symbolically started by sending a first telegram from Zagreb to Vienna on September 28, 1850 at 10:15 a.m. ${ }^{2}$ By that time, the new telegraphing technology had already become very popular on the global level, and further discoveries in the field of electricity and electromagnetism led to the first successful experiments with speech transfer, and finally to the invention of the telephone in $1876 .{ }^{3}$ The first telephone line for official use in Zagreb was put into circulation only five years

\footnotetext{
2 Ivan Štritof, ed., Zbornik u povodu proslave 120-godišnjice uvođenja telegrafa u Hrvatskoj [Festschrift on the $120^{\text {th }}$ anniversary of telegraph in Croatia] (Zagreb: Otokar Keršovani, 1974), p. 38.

3 Anthony R. Michaelis, From Semaphore to Satellite (Geneve: ITU, 1965), p. 96.
} 
later - on January $8,1881 .^{4}$ The key issue after the invention of the telephone was how to connect the telephone subscribers and manage the telephone traffic. If installing individual lines from all telephone subscribers to one other was to be avoided, it was necessary to establish a central place where the subscriber lines crossed. Without it, 19900 air cables would have been needed to establish a network of only 200 telephone subscribers. ${ }^{5}$ This method was not financially viable, it was technically too complex, and would have smothered the promising potential of the new invention from the outset. The problem was solved when the telephone exchange was invented. In the development of telephony, telephone exchanges have such significance that the history of telephony may be rightly identified with the history of telephone exchanges.

The idea of constructing a telephone exchange has been attributed to the Hungarian inventor Tivadar Puskás. ${ }^{6}$ The first telephone exchanges at the end of the 19th century were manual and inductive. Manual because the subscribers were connected manually by telephone operators, and inductive because the initial electrical current (for establishing calls and making the telephone ring) was created by turning the inductor handle. This phase in the telecommunications development is usually called the LB (local battery) phase, since each subscriber had a source of electricity in the form of a galvanic cell (battery) that enabled the conversation. Galvanic cells produce electricity electrochemically. ${ }^{7}$ In practice, the cells produced a direct current of approximately $1.5 \mathrm{~V}$ for the operation of the telephone microphone. The local battery itself usually consisted of two galvanic cells. The wealthier subscribers could connect several batteries into a sequence and thus extend the duration of the conversation. In Croatia, the most common galvanic cells were Meidinger's telegraph unit and Lechlanche's telephony unit. ${ }^{8}$

\footnotetext{
4 Velimir Sokol, Stogodišnjica telefonije u Hrvatskoj [Hundred years of telephony in Croatia] (Zagreb: Radna organizacija PTT prometa Zagreb, 1981), p. 21.

5 Mato Perak, Uvod u eksploataciju telekomunikacija [Introduction to the use of telecommunications] (Zagreb: PTT školski centar, 1970), p. 66.

6 W. Bernard Carlson, Tesla: Inventor of the Electrical Age (Princeton, NJ: Princeton University Press, 2013), 49.

7 "Galvanski članak" [Galvanic cell], entry in: Hrvatska enciklopedija, vol. 4 (Zagreb: Leksikografski zavod "Miroslav Krleža“, 2002), pp. 104-105.

8 Kraljevsko ugarsko ministarstvo trgovine (Royal Hungarian Ministry of Commerce), Naputak za sastavljanje i uzdržavanje Leclanche-ove baterije [Instruction for assembling and maintaining Leclanche’s battery] (Zagreb: Tiskara Mile Maravića, 1902), p. 5.
} 


\section{Zagreb's First Telephone Exchange}

The first telephone exchange in Zagreb intended for public use was located in the city centre, in Krvavi Most Street, and was officially put into operation on January $1,1887 .^{9}$ It was a result of private initiative of the Zagreb-based entrepreneur Vilim Schwarz, who had obtained a 20-year concession for constructing a public telephone network from the Hungarian Ministry of Public Works and Communications..$^{10}$ It was a manual inductor telephone exchange with the capacity of 100 subscribers. Three telephone operators were employed there, manually channelling the telephone traffic through a switchboard: Barbara Rihtarić, Viktorija Soronijević, and Laura Sekulić. ${ }^{11}$ At the time of employment, Barbara Rihtarić was 19 years old, Viktorija Soronijević was 20, and Laura Sekulić was 27, and all three had completed their 8-year education at the higher girls' school, so one may say that they were educated above the average for their time, bearing in mind that the diploma of the said school usually "marked the end of the educational path for women." ${ }^{2}$

When awarding the concession to V. Schwarz on August 7, 1886, the Hungarian Ministry of Public Works and Communications set the condition that devices by Hungarian producers were to be used in constructing the Zagreb telephone network. Article 4 of the Ministry's Permit clearly stated: "For Zagreb, micro-telephones of Vecsey's type are to be used as telephone devices."13 Istvan Vecsey was a long-time official of the Hungarian Royal Telegraph who had ventured into the production of telephones. Favouring the Hungarian producers because of the economic protectionism of the Hungarian authorities would remain a typical feature of Zagreb's telephony almost to the end of World War I. These manufacturers included companies such as "Helios", "Ericsson", "Telefongyár", and "E.I.V.R.T." - all from Budapest. Products of the Budapest branch of "Deckert \& Homolka" from Vienna, which was opened

\footnotetext{
9 Sokol, Stogodišnjica telefonije u Hrvatskoj, 61; “Krvavi most," in: Zagrebački leksikon, vol. 1 (Zagreb: Leksikografski zavod "Miroslav Krleža”, 2006), pp. 558-559.

10 Vilim Schwarz was a member of the reputable Jewish community of Zagreb, which played an important role in the city's development. During his term as the head of the Jewish community, the famous Zagreb synagogue in Praška Street was deplorably destroyed by the NDH regime. His son Ljudevit Schwarz was the first Jewish representative in the Croatian Parliament.

11 HT Museum, Zbirka osobne i službene dokumentacije [Collection of Personal and Official Documentation], Personalni list Barbare Rihtarić [Personal sheet of Barbara Rihtarić], OD-45-1; ibid., Personalni list Viktorije Soronijević [Personal sheet of Viktorija Soronijević], OD-47-1; ibid., Personalni list Laure Sekulić [Personal sheet of Laura Sekulić], OD-46-1.

12 Ida Ograjšek Gorenjak, "Otvaranje ženskog liceja u Zagrebu" [Establishment of the girls' lyceum in Zagreb], Povijest u nastavi 8 (2006), 147.

13 HT Museum, Collection of Personal and Official Documentation, Dozvolbena isprava [Permit], OD-43-7.
} 
precisely due to strong Hungarian efforts to establish their own production of telephones, played an exceptional role in this respect. ${ }^{14}$ In addition, Croats did not enjoy equal treatment in the postal-telegraph-telephone services compared to the Hungarians, on the contrary: "the Hungarian bureaucratic system neglected and prevented them in promotion more than anyone else." 15 With the inauguration of the telephone exchange, Zagreb became the first city in Croatia with a public telephone network. As for Rijeka, a license for constructing a public telephone network was issued on March 25, 1890, for Osijek in 1892, while in Split, a manual inductor exchange with a capacity of 50 subscribers was put into operation on April 6, $1895 .^{16}$

In 1897, telephony in Zagreb was still local in its character. Although Zagreb was connected both with Vienna and with Budapest via telegraph, in telephony, unfortunately, Zagreb was "still not connected to any other city." Its telephone connections to Varaždin, Vienna, Budapest, and some smaller cities were established on December $18,1898 .{ }^{18}$ Due to the unfavourable political and historical circumstances, the residents of Zagreb and northern Croatia would sooner be able to talk to Budapest and Vienna than to the Croatian seaside towns. It was only on November 15, 1913 that telephone connections were established between Zagreb and Dalmatia. ${ }^{19}$ Thus, the telephone started to connect the politically divided and communicationally disconnected Croatian territories at a relatively late date.

\section{State Control over Zagreb’s Telephone Network}

When the state realized the significance and broad implications of the new technology, and its promising potential for the state treasury, Schwarz's telephone network was placed under state control on January 1, 1894. On April 9, 1895, a new manual inductor telephone exchange was put into circulation,

\footnotetext{
14 Artur Attman, Jan Kuuse, and Ulf Olsson, LM Ericsson 100 Years: The Pioneering Years, Struggle for Concessions Crisis 1876 - 1932 (Stockholm: LM Ericsson, 1977), 209.

15 Katica Klarić, “Ženski asistenti i pomoćni kontrolori” [Women assistants and supporting controllers], Pošta - glasilo poštanskih, brzojavnih i telefonskih namještenika u Državi SHS (January 15, 1919), 10.

16 Nedjeljko Nižić, Pregled povijesti pošte, brzojava i telefona u Hrvatskoj [Overview of the history of postal service, telegram, and telephone in Croatia] (Zagreb: Grafički zavod Hrvatske, 2007), pp. 500,582 , and 625 .

17 Oton Kučera, Magnetizam i elektricitet [Magnetism and electricity] (Zagreb: Dionička tiskara, 1897), 98.

18 Viktor Hajnrih, "Prva 'interurbanska' telefonska 'sveza' Zagreb" [The first "interurban" telephone "connection" Zagreb], PTT radnik - list radne zajednice poduzeća ptt saobraćaja Zagreb 4 (April 1, 1977), 14.

19 Nižić, Pregled povijesti pošte, brzojava i telefona u Hrvatskoj, p. 133.
} 
with the capacity of 500 subscribers, located in the building at the corner of Gajeva and the then Nikolićeva (today's Teslina) Street. ${ }^{20}$ From that moment on, telephony continued its development symbolically under the state control. At the moment of launching the new telephone exchange, only 178 subscribers were connected to it. ${ }^{21}$ Obviously counting upon a significant increase in the number of telephone subscribers, and in order to facilitate the work of telephone operators, it was announced that when calling the central exchange, the subscribers would no longer have to ask for a person by their name, but by the corresponding subscriber number. ${ }^{22}$

For various reasons, manual inductor telephone exchanges were used for quite a long time between the marginal parts of the city and its satellite settlements. As late as 1981, we learn that in the vicinity of "large urban and industrial centres such as Zagreb and Sisak, the old and already derelict LB exchanges are still in use, although they do not meet even the minimum of requirements." ${ }^{23}$ The greatest drawback of the local battery system was that they could not maintain a reliable voltage in the galvanic cells distributed over the network, and the quality of conversations, among other things, largely depended on that. For this reason, a system of supplying the network with electricity through a central battery from the telephone exchange itself was designed. Thus, the next phase in its development is called CB (central battery) telephony. ${ }^{24}$

\section{The First Telephone Exchange with a Central Battery (CB Exchange)}

The first $\mathrm{CB}$ telephone exchange in Zagreb was put into operation on October 31, 1904. ${ }^{25}$ It was located in the Post Office building in Jurišićeva Street, which was built especially for the purpose of improving the postal-telegraph-telephone system. With this building, Zagreb's telephony first obtained suitable accommodation, and in different locations within the same building, telephone exchanges would live to see the $21^{\text {st }}$ century. The switchboard (product of the Hungarian company "EIVRT" from Budapest) had a capacity of 750 subscribers and 30 interurban lines, and its operation was connected

\footnotetext{
20 "Die neue Telephon-Centrale," Agramer Zeitung 82 (April 9, 1895), 4; Petar Balestrin, "Sto godina telefonije u Zagrebu" [Hundred years of telephony in Zagreb], PTT radnik - list radne ptt organizacije Zagreb (prilog) (August 1981), V.

21 "Die neue Telephon-Centrale," 4.

22 Ibidem.

23 Miroslav Bijele, "Kako do boljih veza?" [How to obtain better connections?], PTT radnik - list radne ptt organizacije Zagreb (September-October 1981), 7.

24 Vojislav Ranković, Automatska telefonija [Automatic telephony] (Belgrade: Tehnička knjiga, 1962), p. 12.

25 "Die neue Telephon-Centrale," 5.
} 
to the installation of the first system of telephone cables cast in concrete in Zagreb, from Palmotićeva Street over Jelačić Square to Frankopanska Street. ${ }^{26}$ Work on the upgrade of the telephone network was first slowed down and then completely interrupted by the outbreak of World War I in 1914. In the aftermath of the war, there was a high demand for new telephone connections and telephone equipment in Zagreb, but the lines were overloaded with military talks (of the French troops in Zagreb), there was a lack of material and construction workers, and the telephone devices were worn out and often broken..$^{27}$ In this situation, as it was impossible to find better solutions, an inductive sub-exchange with the capacity of 200 call numbers was installed in 1920 in the dilapidated Post Office Zagreb 2 at the central railway station (today's Branimirova Street), and in 1921 another CB sub-exchange with the capacity of 200 subscribers in the Post Office Zagreb 6 in Wilson's Square 2 (today's Square of the Republic of Croatia). ${ }^{28}$ However, these additions could not meet the increasing need of Zagreb's residents for telephone or solve the essential problems of telephony, because at the time of highest traffic at the telephone exchange, "there was such rush that the telephone operators could not manage, or barely managed all the calling numbers." ${ }^{29}$ These hindrances that the subscribers had to face on a daily basis with $\mathrm{CB}$ telephone exchanges created such a mood in the public that it became urgent to introduce modern, automatic telephone exchanges.

\section{Zagreb's First Automatic Telephone Exchange}

The first Croatian automatic telephone exchange, with the capacity of 5000 subscribers, was put into circulation on April 1, 1928 in Zagreb, with the possibility of expanding to accommodate 7000 subscribers. ${ }^{30}$ It was of the "step-bystep" type. ${ }^{31}$ Zagreb was the third city in the Kingdom of SHS that obtained an

\footnotetext{
26 Dragan Bach, “40 godišnjica automatske telefonske centrale u Zagrebu - značajan jubilej" [40 ${ }^{\text {th }}$ anniversary of automatic telephone exchange in Zagreb - an important jubilee], PTT radnik - list radne ptt organizacije Zagreb (April 1, 1968), 3.

27 HT Museum, Archive, Okružnica Br. 50360/1919. [Circular no. 50360/1919], Box 001.

28 Imenik telefonskih pretplatnika [Telephone book] (Zagreb: Direkcija pošta i telegrafa, 1922), p. 77.

29 Dragutin Katušić, "Automatski telefonski uređaj u Zagrebu" [Zagreb’s automatic telephone device], Pošta - organ oblasnih organizacija poštanskih, telegraf. i telefon. službenika u Zagrebu i Splitu (April 1, 1928), 33.

30 Nižić, Pregled povijesti pošte, brzojava i telefona u Hrvatskoj, p. 138.

31 "Step-by-step" telephone exchanges owe their name to the way in which telephone calls were established. By dialing each digit of the telephone number separately, the subscriber sent a series of electrical impulses that controlled the operation of the switching elements on the switchboard, thus selecting the number "step by step" and initiating a call to the desired subscriber.
} 
automatic telephone exchange. On April 17, 1927, Novi Sad obtained one, and on April 19 that same year Ljubljana. ${ }^{32}$ However, it should be emphasized that Zagreb's telephone exchange had a much larger capacity, and that Zagreb was the first city in the country with an automatic telephone exchange for 5000 telephone connections. All exchanges were obtained as part of the war reparations that Germany had to pay after the end of World War I, and stemmed from the German company Siemens \& Halske from Berlin. ${ }^{33}$ Since there were no expert telecommunications technicians in Zagreb at that time, the installation was carried out by German technicians. The works were supervised by Zagreb's engineer Dragutin Katušić as the head of the TT department, and as for the local experts (besides Katušić, who had been trained at the Technical College in Prague), two telephone mechanics trained in Berlin, Josip Sauter and Krešimir Tretinjak, also took part. ${ }^{34}$

The call numbers in Zagreb's automatic telephone exchange were four-digit. Interurban conversations had to be announced separately, and interferences could also be reported. Starting with the operation of this telephone exchange in Zagreb, new elements appeared on telephone devices - rotary dials - enabling the subscribers in the local traffic to dial the numbers on their own, without the mediation of telephone operators. The subscriber network in the Zagreb area was only partially cabled and mostly airborne, especially towards the periphery. With such a network, the functioning of the central exchange was highly dependent on weather and the seasons. In winter, the accumulated snow and ice often damaged the airborne cables, which had a negative impact on the quality of connections. Nevertheless, according to the contemporary testimonies, the main advantages of the new technology were the fast, 6-second connection, accurate switching, uninterrupted operation, and the possibility to have conversations without being overheard..$^{35}$ The central exchange was a great improvement in Zagreb's telephony during the interwar period, but fell victim to a Partisan sabotage during World War II. On September 14,1941 , it was blown up and remained out of operation for several months. ${ }^{36}$ Nevertheless, in spite of the sabotage, the exchange remained at the service of Zagreb's telephone subscribers for 51 years, until in April 1980 it was replaced

\footnotetext{
32 "Otvaranje automatskih centrala" [Installation of automatic exchanges], Poštansko-telegrafski Vesnik 7 (January 1, 1928), 114.

33 Katušić, "Automatski telefonski uređaj u Zagrebu," 33.

34 Velimir Sokol, "Pola stoljeća zagrebačke automatske telefonske central" [Half a century of Zagreb's automatic telephone exchange], PTT radnik - list radne organizacije poduzeća ptt saobraćaja Zagreb (April-May 1978), 10-11.

35 Katušić, "Automatski telefonski uređaj u Zagrebu," 34.

36 Slavko Markon, "Diverzija na zagrebačku telefonsku central” [Sabotage at Zagreb’s telephone exchange], PTT arhiv 6 (1961), 123.
} 
by a new system, with the crossbar exchanges ARF-50 and ARF-102. ${ }^{37}$ Despite not being intended for such a long service and met with considerable objective difficulties in its operation, the old central exchange was the backbone of Zagreb's telephone network for more than half a century.

\section{Decentralization of Zagreb's Telephone Network with the Introduc- tion of Crossbar Exchanges ARF-50 and ARF-102}

In the period after World War II, difficult social and economic conditions also affected telephony in Zagreb, and there was no constructive response to the need of expanding the subscriber capacities and improving the network. The complex geopolitical position of FNR Yugoslavia between East and West certainly did not make the situation any better, as it made it difficult to purchase sophisticated telecommunications equipment for which there was no adequate domestic production. Only one expansion of Zagreb's automatic telephone exchange took place in 1947, by 1000 connections, which was certainly far from enough for the centre of the People's Republic of Croatia and a city that was considered as one of the strongest in the country in terms of economy, culture, and administration. In 1954, Zagreb had only 2.83 phones per 100 inhabitants, which was poorer even in comparison with the data from the pre-war year of 1939 , when there were 2.98 phones per 100 inhabitants. ${ }^{38}$ Justification cannot be found in the post-war demographic expansion of the city, since very little was done to construct and expand the telephone network. Until as late as 1955, telephone subscribers from the city districts of Kustošija in the west to Dubrava in the east had to rely on the increasingly unreliable, old automatic telephone exchange, which was overloaded and prone to malfunction. In the following forty years, it would become evident that urban and demographic growth, as well as vigorous economic activity, was not paralleled by a corresponding growth in the subscriber capacities of public automated telephony. However, two moments fundamentally marked Zagreb's telephony in the decade immediately after the end of the war. The first was the establishment of the "Nikola Tesla" Telephone Factory on November 1, 1949. ${ }^{39}$ In the following years, its partially provided the necessary crossbar telephone

\footnotetext{
37 Petar Balestrin, "60 godina automatske telefonije u Zagrebu" [60 years of automatic telephony in Zagreb], PTT radnik - list radne ptt organizacije Zagreb (July 1988), 5.

38 RO PTT prometa Zagreb, Statistika izvora telekomunikacionog prometa na području RO PTT prometa Zagreb 31.12.1970. [Statistics on the sources of telecommunications traffic in the area of RO PTT Zagreb, December 31, 1970] (Zagreb: Odjel za razvoj ptt saobraćaja - odsjek za telekomunikacije, 1971), p. 10.

39 Snježana Bahtijari, ed., 60 godina Ericsson Nikola Tesla 1949-2009 [60 years of Ericsson Nikola Tesla, 1949-2009] (Zagreb: Ericsson Nikola Tesla, 2009), p. 57.
} 
exchanges for the purpose of expanding the telephone network, all thanks to a license agreement with the Swedish company "LM Ericsson". ${ }^{40}$ Another significant event was recorded on June 19, 1955, when the hitherto latest type of automatic telephone exchange was put into operation, based on the crossbar system. The crossbar system was known to be very reliable and cost-effective in comparison to the previous step-by-step exchanges provided by Siemens. Stepby-step exchanges were both labour-intensive and materially costly in terms of maintenance, and modest in terms of handling telephone calls. Furthermore, at that time the purchase price of one crossbar connector was US $\$ 80$ (US\$ 10 more than Siemens), but the maintenance and material costs per connection were incomparably lower (US\$ 3.55 per crossbar connection as compared to US\$ 22.66 for Siemens' step-by-step connection). ${ }^{41}$ The exchange itself was located at Peščenica (today's Harambašićeva Street No. 39) and was therefore called ATC Peščenica. The selection of this location was not accidental, as an industrially potent part of the city was located nearby - Žitnjak. In the period of lacking telephone numbers, the authorities were trying to provide additional telephone capacities at least for the needs of production plants of growing importance. The following companies, among others, received telephone connections: "Prvomajska", "Radioindustrija Zagreb", "Elektroda", "Zagrebačka mljekara”, "Žitnjak", "Braća Kavurić”, "Kontakt”, "Munja”, "Fotokemika”, "Etilen", "Naftaplin", "Chromos", "Koteks", "Viadukt", “TEŽ", "Lipa Mill”, "Tvornica parnih kotlova", "Ghetaldus", and "Labud". ${ }^{42}$ Already the following year, in 1956, a telephone sub-exchange for the city district of Dubrava was connected to the Peščenica exchange, with a modest capacity of 100 subscribers. The central exchange was of the ARF-50 type with the initial capacity of 1000 subscribers, a product of the Swedish company "LM Ericsson". The ARF-50 system was compatible with Zagreb's old "step-by-step" automatic exchange, and therefore an ideal choice for the modernization of the city's telephone network. Telephone subscribers connected to the new exchange received five-digit call numbers beginning with $41{ }^{43}$

The construction and inauguration of ATC Peščenica was a breakthrough in the development of Zagreb's telephony, since it marked the beginning of decentralization in the telephone network, which would allow for more tele-

40 Milan Lacković, "10 godina Crossbar-centrala" [10 years of crossbar exchanges], PTT radnikglasilo radnog kolektiva ptt saobraćaja Zagreb 6 (June 1, 1965), 2.

41 HT Museum, Archive, Projekt za izgradnju i montažu RC "Peščenica" Zagreb (ekonomsko obrazloženje) [Plan for the construction and assemblage of RC "Peščenica", Zagreb (financial project], box 339 .

42 Telefonski imenik poduzeća p.t.t. saobraćaja Zagreb 1956 [Telephone book of the PTT traffic company Zagreb, 1962] (Zagreb: Poduzeće PTT saobraćaja Zagreb, 1956), pp. 324-328.

43 HT Museum, Archive, Projekt za izgradnju i montažu RC "Peščenica". 
phone subscribers in individual city districts. When ATC Peščenica proved successful in its operation, the same type of exchange system (ARF-50) started to be installed in other parts of the city. At the beginning, they were planned to have an equal subscriber capacity of 2000 call numbers, with the possibility of later upgrading. The sequence was started on December 1, 1958 with ATC Trnje and continued on May 22, 1961 with ATC Trešnjevka, and then on August 16, 1962 with ATC Črnomerec for the western part of the city. ${ }^{44}$ On May 25, 1964, ATC Center II (today's Draškovićeva Street No. 26) was put into operation, with 4000 call numbers, and the last telephone exchange of the ARF50 type was inaugurated on May 9, 1969: ATC Trnsko with the capacity of 5000 subscribers. ${ }^{45}$ All these changes were mainly aiming at the improvement of the local telephone network, but the role of telephony in long-distance communication surpasses the borders of a city by far, and its advantages are best seen in interurban and international telephone traffic. For more than 60 years, interurban telephone traffic in Zagreb took place with the manual mediation of telephone operators. In the old part of the building at Jurišićeva Street No. 13, "around a hundred" telephone operators managed the interurban calls of the subscribers by manually directing them through switchboards. ${ }^{46}$ In 1962, a telephone subscriber in Zagreb wishing to make an interurban call still first had to dial 00, then tell the telephone operator which number he wanted to contact and what the nature of his call was. ${ }^{47}$ On May 24, 1964, the transit telephone exchange Zagreb (of the crossbar type ARM 201/2) was put into operation, enabling automated interurban telephone calls. ${ }^{48}$ From then on, $\mathrm{Za}$ greb had its own distinctive call number 041 in SFRJ. Automated international telephone calls were possible from July 27, 1976, and the first call was - tellingly - established with the embassy of SFR Yugoslavia in Sweden. ${ }^{49}$ The relatively successful application of the ARF-50 type exchanges paved the way for installing the upgraded ARF-102 type, which had a higher subscriber capacity. The first such automatic telephone exchange opened in Zagreb's city district

\footnotetext{
44 Balestrin, "Sto godina telefonije u Zagrebu," VII.

45 Ibidem.

46 Martin Krpan, "Susret uoči 8. marta - Dvije generacije" [An encounter before the $8^{\text {th }}$ of March - Two generations], PTT radnik - glasilo radnog kolektiva ptt saobraćaja Zagreb (March 1, 1966), 1.

47 Telefonski imenik poduzeća p.t.t. saobraćaja Zagreb 1962 [Telephone book of the PTT traffic company Zagreb, 1962] (Zagreb: Poduzeće PTT saobraćaja Zagreb, 1962), pp. 9-10.

48 Zora Gotal, "Halo, svijete, ovdje Zagreb” [Hello world, Zagreb here], PTT radnik - list radne ptt organizacije Zagreb (September 1986): 1.

49 M. Z., "Izvršenje programa razvoja 1969-1975. godine" [Finalization of the development programme 1969-1975], PTT radnik - list radne organizacije poduzeća ptt saobraćaja Zagreb (September 1, 1976): 1; this exchange was of the ARM 202/4 crossbar type. Cooperation between the Swedish company "LM Ericsson" and Zagreb's factory "Nikola Tesla" was crucial for the modernization of local, interurban, and international telecommunications.
} 
of Dubrava on December 31, 1974, with a capacity of 5000 call numbers. ${ }^{50}$ The inauguration of this exchange marked the beginning of the slow process of "popularizing" the telephone. From a status symbol implying a social position that was hard to reach for an ordinary citizen, the telephone in Zagreb slowly, by installing more exchanges of this type, started to find its way to private users. Along with the exchange in Dubrava, by 1981 there were several other ARF-102 automatic telephone exchanges: Centar I, Trnje II, Peščenica, and Utrine. ${ }^{51}$ Due to the decentralization of the local telephone network, Zagreb reached the number of 112,060 telephone connections by 1981, with a density of 15.99 per 100 inhabitants, which means that, compared to 1961 when there were 3.40 phones per 100 inhabitants, the number of telephone subscribers had increased almost five times. ${ }^{52}$ However, even with such statistics, Zagreb was lagging behind several Eastern European cities. Thus, in 1980, Zagreb had a smaller density of main telephone connections than Prague, Bratislava, Budapest, Ljubljana, and Belgrade. ${ }^{53}$ In the shadow of electromechanical exchanges with crossbar switchboards, which were the backbone of Zagreb's telephone network, new semi-electronic telephone exchanges of the ARE-11 type and electronic ones of the AX-10 type emerged in the late 1970s and early 1980s, with incomparably larger capacities and connection possibilities that ensured easier access to public telephony in Zagreb. The first electronic telephone exchange of the AX-10 type was put into operation in 1981, in the city district of Vrapče, ${ }^{54}$ in experimental mode. Thus, the $100^{\text {th }}$ anniversary of telephony in Zagreb was celebrated with a technology that would usher it into the 21st century.

\section{CONCLUSION}

In the course of its 100-year development, Zagreb's telephony strove to follow all global trends and apply the latest achievements in telephony (from the

\footnotetext{
50 Josip Jambrošić, “Okrugli stol s novinarima Vjesnika” [A round table with Vjesnik’s reporters], PTT radnik - list radne organizacije poduzeća ptt saobraćaja Zagreb (June 1, 1975), 9.

51 Zdenko Palata and Branimir Janković, "Prioritetna investicija u planu 1981.-1985." [Priority investment for the period 1981-1985], PTT radnik - list radne ptt organizacije Zagreb (March 1, 1981), 12.

52 RO PTT prometa Zagreb, Statistika izvora telekomunikacionog prometa na području RO PTT prometa Zagreb 31.12.1981. [Statistics on the sources of telecommunications traffic in the area of RO PTT Zagreb, December 31, 1981] (Zagreb: Sektor razvoja ptt prometa - odsjek telekomunikacija, 1982), 9.

53 Zvonimir Jakobčić, "Stanje telefonije u Europi 31. XII 1980. godine s kratkim osvrtom na telefoniju u svijetu" [The state of telephony in Europe on December 31, 1980, with a brief overview of global telephony], PTT radnik - list radne ptt organizacije Zagreb (May 1983), 4-5.

54 RO PTT prometa Zagreb, "Nikola Tesla" Zagreb, Vrapče AXE 10 Zagreb (Zagreb: OOUR Gradski telefon, "Nikola Tesla", 1981), 2.
} 
very emergence of the telephone to the creation of a public telephone network and the automation of local, interurban, and international telephone traffic), even in comparison with Western European cities. During this period, it progressed from hand-switched analogue telephony to electronically controlled telephone exchanges. However, these efforts did not result in an appropriate quantitative breakthrough in the number of telephone subscribers, and many citizens who wanted to use telephone were deprived of this possibility due to the qualitative shortcomings of Zagreb's urban telephone network. Even in the early 1980s, the number of telephone subscribers and the density of telephone connections in Zagreb were still not at a level comparable to other, similar European cities. Significant changes followed only when the older electromechanical telephone exchanges were replaced by new, electronic digital telephone exchanges, which raised the quality of telephone communication to a completely new level.

\section{Bibliography}

\section{Archival Sources}

HT Museum, Collection of Personal and Official Documentation, Dozvolbena isprava [Permit], OD-43-7.

HT Museum, Archive, Okružnica Br. 50360/1919. [Circular no. 50360/1919], box 001.

HT Museum, Collection of Personal and Official Documentation, Personalni list Barbare Rihtarić [Personal sheet of Barbara Rihtarić], OD-45-1.

HT Museum, Collection of Personal and Official Documentation, Personalni list Viktorije Soronijević [Personal sheet of Viktorija Soronijević], OD-47-1.

HT Museum, Collection of Personal and Official Documentation, Personalni list Laure Sekulić [Personal sheet of Laura Sekulić', OD-46-1.

HT Museum, Archive, Projekt za izgradnju i montažu RC "Peščenica" Zagreb (ekonomsko obrazloženje) [Plan for the construction and assemblage of RC “Peščenica”, Zagreb (financial project], box 339. 


\section{Literature}

Attman, Artur, Jan Kuuse, and Ulf Olsson. LM Ericsson 100 Years: The Pioneering Years, Struggle for Concessions Crisis 1876 - 1932, Stockholm: LM Ericsson, 1977.

Bahtijari, Snježana, ed. 60 godina Ericsson Nikola Tesla 1949-2009 [60 years of Ericsson Nikola Tesla, 1949-2009]. Zagreb: Ericsson Nikola Tesla, 2009.

Carlson, W. Bernard. Tesla: Inventor of the Electrical Age. Princeton, NJ: Princeton University Press, 2013.

"Galvanski članak" [Galvanic cell], entry in: Hrvatska enciklopedija, vol. 4 (Zagreb: Leksikografski zavod "Miroslav Krleža", 2002), 104-105.

Imenik telefonskih pretplatnika [Telephone book]. Zagreb: Direkcija pošta i telegrafa, 1922.

Kraljevsko ugarsko ministarstvo trgovine (Royal Hungarian Ministry of Commerce). Naputak za sastavljanje i uzdržavanje Leclanche-ove baterije [Instruction for assembling and maintaining Leclanche's battery]. Zagreb: Tiskara Mile Maravića, 1902.

"Krvavi most", in: Zagrebački leksikon, vol. 1 (Zagreb: Leksikografski zavod "Miroslav Krleža", 2006), 558-559.

Kučera, Oton. Magnetizam i elektricitet [Magnetism and electricity]. Zagreb: Dionička tiskara, 1897.

Michaelis, R. Anthony. From Semaphore to Satellite, Geneve: ITU, 1965. Markon, Slavko. "Diverzija na zagrebačku telefonsku centralu" [Sabotage at Zagreb's telephone exchange], PTT arhiv 6 (1961): 115-126.

Nižić, Nedjeljko. Pregled povijesti pošte, brzojava i telefona u Hrvatskoj [Overview of the history of postal service, telegram, and telephone in Croatia]. Zagreb: Grafički zavod Hrvatske, 2007.

Ograjšek Gorenjak, Ida. "Otvaranje ženskog liceja u Zagrebu” [Establishment of the girls' lyceum in Zagreb], Povijest u nastavi 8 (2006): 147-176.

Perak, Mato. Uvod u eksploataciju telekomunikacija [Introduction to the use of telecommunications]. Zagreb: PTT školski centar, 1970.

Ranković, Vojislav. Automatska telefonija [Automatic telephony]. Belgrade: Tehnička knjiga, 1962.

RO PTT prometa Zagreb, Statistika izvora telekomunikacionog prometa na području RO PTT prometa Zagreb 31.12.1970. [Statistics on the sources of telecommunications traffic in the area of RO PTT Zagreb, December 31, 1970]. Zagreb: Odjel za razvoj ptt saobraćaja - odsjek za telekomunikacije, 1971. 
Statistika izvora telekomunikacionog prometa na području $R O$ PTT prometa Zagreb 31.12.1981. [Statistics on the sources of telecommunications traffic in the area of RO PTT Zagreb, December 31, 1981]. Zagreb: Sektor razvoja ptt prometa - odsjek telekomunikacija, 1982.

. "Nikola Tesla" Zagreb, Vrapče AXE 10 Zagreb. Zagreb: OOUR Gradski telefon, "Nikola Tesla", 1981.

Sokol, Velimir. Stogodišnjica telefonije u Hrvatskoj [Hundred years of telephony in Croatia]. Zagreb: Radna organizacija PTT prometa Zagreb, 1981.

Telefonski imenik poduzeća p.t.t. saobraćaja Zagreb 1956 [Telephone book of the PTT traffic company Zagreb, 1956]. Zagreb: Poduzeće PTT saobraćaja Zagreb, 1956.

Telefonski imenik poduzeća p.t.t. saobraćaja Zagreb 1962 [Telephone book of the PTT traffic company Zagreb, 1962]. Zagreb: Poduzeće PTT saobraćaja Zagreb, 1962.

Štritof, Ivan, ed. Zbornik u povodu proslave 120-godišnjice uvođenja telegrafa $u$ Hrvatskoj [Festschrift on the $120^{\text {th }}$ anniversary of telegraph in Croatia]. Zagreb: Otokar Keršovani, 1974.

\section{Daily Press}

Bach, Dragan. “40 godišnjica automatske telefonske centrale u Zagrebu značajan jubilej" [ $40^{\text {th }}$ anniversary of automatic telephone exchange in Zagreb - an important jubilee], PTT radnik - list radne ptt organizacije Zagreb (April 1, 1968): 3.

Balestrin, Petar. "Sto godina telefonije u Zagrebu" [Hundred years of telephony in Zagreb], PTT radnik - list radne ptt organizacije Zagreb (prilog) (August 1981): V-VIII.

"60 godina automatske telefonije u Zagrebu" [60 years of automatic telephony in Zagreb], PTT radnik - list radne ptt organizacije Zagreb (July 1988): 5.

Bijele, Miroslav. "Kako do boljih veza?" [How to obtain better connections?], PTT radnik - list radne ptt organizacije Zagreb (September-October 1981): 7.

"Die neue Telephon-Centrale," Agramer Zeitung (April 9, 1895): 4.

"Die neue Telephoncentrale," Agramer Zeitung (October 29, 1904): 5.

Gotal, Zora. "Halo, svijete, ovdje Zagreb” [Hello world, Zagreb here], PTT radnik - list radne ptt organizacije Zagreb (September 1986): 1-2. 
Hajnrih, Viktor. "Prva 'interurbanska' telefonska 'sveza' Zagreb” [The first "interurban" telephone "connection" Zagreb], PTT radnik - list radne zajednice poduzeća ptt saobraćaja Zagreb (April 1, 1977): 14.

Jakobčić, Zvonimir. "Stanje telefonije u Europi 31. XII 1980. godine s kratkim osvrtom na telefoniju u svijetu" [The state of telephony in Europe on December 31, 1980, with a brief overview of global telephony], PTT radnik - list radne ptt organizacije Zagreb (May 1983), 1-5.

Jambrošić, Josip. "Okrugli stol s novinarima Vjesnika” [A round table with Vjesnik's reporters], PTT radnik - list radne organizacije poduzeća ptt saobraćaja Zagreb (June 1, 1975): 7-10.

Katušić, Dragutin. “Automatski telefonski uređaj u Zagrebu” [Zagreb’s automatic telephone device], Pošta - organ oblasnih organizacija poštanskih, telegraf. i telefon. službenika u Zagrebu i Splitu (April 1, 1928): 33-34.

Klarić, Katica. "Ženski asistenti i pomoćni kontrolori” [Women assistants and supporting controllers], Pošta - glasilo poštanskih, brzojavnih i telefonskih namještenika u Državi SHS (January 15, 1919): 9-10.

Krpan, Martin. "Susret uoči 8. marta - Dvije generacije" [An encounter before the 8th of March - Two generations], PTT radnik - glasilo radnog kolektiva ptt saobraćaja Zagreb (March 1, 1966): 1.

Lacković, Milan. "10 godina Crossbar-centrala” [10 years of crossbar exchanges], PTT radnik-glasilo radnog kolektiva ptt saobraćaja Zagreb 6 (June 1, 1965): 2.

"Otvaranje automatskih centrala" [Installation of automatic exchanges], Poštansko-telegrafski Vesnik 1928 (January 1, 1929): 114.

Palata, Zdenko and Branimir Janković. "Prioritetna investicija u planu 1981. - 1985." [Priority investment for the period 1981-1985], PTT radnik - list radne ptt organizacije Zagreb (March 1, 1981): 12-13.

Sokol, Velimir. "Pola stoljeća zagrebačke automatske telefonske centrale" [Half a century of Zagreb's automatic telephone exchange], PTT radnik - list radne organizacije poduzeća ptt saobraćaja Zagreb (April-May 1978): 10-11.

Z., M. "Izvršenje programa razvoja 1969-1975. godine" [Finalization of the development programme 1969-1975], PTT radnik - list radne organizacije poduzeća ptt saobraćaja Zagreb (September 1, 1976): 1. 